\title{
Climate change vulnerability, water resources and social implications in North Africa
}

\author{
Janpeter Schilling ${ }^{1,2} \cdot$ Elke Hertig $^{3} \cdot$ Yves Tramblay $^{4}$ • Jürgen Scheffran ${ }^{5}$ \\ Received: 24 September 2018 / Accepted: 27 October 2019 / Published online: 7 February 2020 \\ (C) The Author(s) 2020
}

\begin{abstract}
North Africa is considered a climate change hot spot. Existing studies either focus on the physical aspects of climate change or discuss the social ones. The present article aims to address this divide by assessing and comparing the climate change vulnerability of Algeria, Egypt, Libya, Morocco, and Tunisia and linking it to its social implications. The vulnerability assessment focuses on climate change exposure, water resources, sensitivity, and adaptive capacity. The results suggest that all countries are exposed to strong temperature increases and a high drought risk under climate change. Algeria is most vulnerable to climate change, mainly due to the country's high sensitivity. Across North Africa, the combination of climate change and strong population growth is very likely to further aggravate the already scarce water situation. The so-called Arab Spring has shown that social unrest is partly caused by unmet basic needs of the population for food and water. Thus, climate change may become an indirect driver of social instability in North Africa. To mitigate the impact of climate change, it is important to reduce economic and livelihood dependence on rain-fed agriculture, strengthen sustainable land use practices, and increase the adaptive capacity. Further, increased regional cooperation and sub-national vulnerability assessments are needed.
\end{abstract}

Keywords Climate change $\cdot$ Vulnerability $\cdot$ Resilience $\cdot$ Water $\cdot$ Conflict $\cdot$ North Africa

\section{Introduction}

North Africa is often considered a "climate change hotspot" (e.g., Diffenbaugh and Giorgi 2012) that has been receiving increasing attention in recent years, particularly from natural and social scientists. Climatologists, for instance, have emphasized the high year-to-year variability of rainfall amounts

This article is part of the Topical Collection on Climate change impacts in the Mediterranean

Electronic supplementary material The online version of this article (https://doi.org/10.1007/s10113-020-01597-7) contains supplementary material, which is available to authorized users.

Janpeter Schilling

schilling@uni-landau.de

Elke Hertig

elke.hertig@geo.uni-augsburg.de

Yves Tramblay

yves.tramblay@ird.fr

Jürgen Scheffran

juergen.scheffran@uni-hamburg.de and the related drought periods and heat waves (Cook et al. 2016; Lelieveld et al. 2016). Several researchers have studied the impact of climate change on the water situation and agriculture. For example, Schmitz et al. (2013) project increased water scarcity in North Africa, while Alboghdady and El-Hendawy (2016) show that a $1 \%$ increase in temperature in the winter results in a $1.12 \%$ decrease in agricultural

1 Research Group Landuse Conflicts, Institute for Environmental Sciences, University of Koblenz-Landau, Fortstraße 7, 76829 Landau, Germany

2 Peace Academy Rhineland-Palatinate, Landau, Germany

3 Faculty of Medicine, Augsburg University, Augsburg, Germany

4 HydroSciences Montpellier (University of Montpellier, CNRS, IRD), Montpellier, France

5 Research Group Climate Change and Security (CLISEC), Center for Earth System Research and Sustainability (CEN), Institute of Geography, University of Hamburg, Hamburg, Germany 


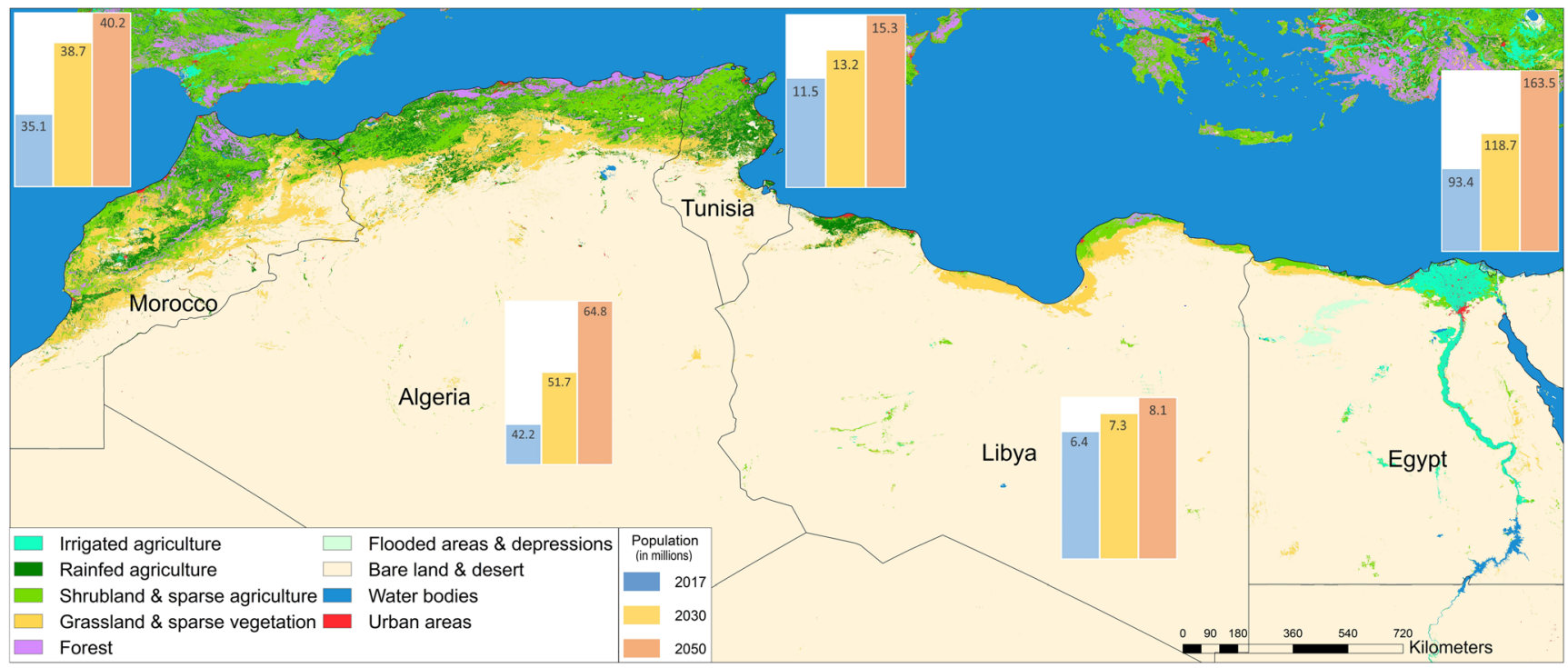

Fig. 1 Land use, topography, and population growth in North Africa (Syed Zulfiqar Ali Shah for the authors based on ESA 2015a; ESA 2015b; PRB 2017)

production in the Middle East and North Africa (MENA) region. Some social scientists have argued that water scarcity in the MENA region is a "man-made problem" (Haddadin 2001:462) and mostly caused by strong population growth (see also Fig. 1). Others have stressed that less rainfall and more erratic rainfall are major drivers of water scarcity which will most strongly affect the poor population in rural areas (Thomas 2008). Scheffran et al. (2019) state that in regions depending on rain-fed agriculture, droughts can increase the risk of civil conflict (see also Schilling and Krause 2018). The papers by Waha et al. (2017) and Schilling et al. (2012) are two examples of a very limited body of integrative literature covering both physical and social aspects of climate change and vulnerability in North Africa. The present article contributes to this literature by assessing and comparing the climate change vulnerability of Algeria, Egypt, Libya, Morocco, and Tunisia and linking it to its social implications. Figure 1 shows the study area, including topography, land use, and projected population growth. Section 2 describes the conceptual framework, while Sect. 3 assesses and compares the climate change vulnerability of the North African countries. A particular focus is placed on the impact of climate change on water resources, which are crucial to human livelihoods in North Africa. Section 4 then assesses the social implications, including the influence of water and food on societal stability and the risk of violent conflict. The paper concludes with Sect. 5, which summarizes key findings and gives recommendations to reduce climate change vulnerability and its negative social implications in North Africa.

\section{Conceptual framework}

Vulnerability is the key guiding concept of this article. Since we want to be able to compare our results to
Schilling et al. (2012), who use the Intergovernmental Panel on Climate Change's (IPCC) vulnerability definition from 2007, we also use this definition, which considers vulnerability as being composed of sensitivity, adaptive capacity, and exposure (IPCC 2007). Figure 2 gives further details of the elements of vulnerability and how we define and operationalize them in this paper. Following the IPCC, we further divide the adaptive capacity into generic adaptive capacity and impact-specific adaptive capacity. "Generic indicators include factors such as education, income and health. Indicators specific to a particular impact, such as drought or floods, may relate to institutions, knowledge and technology" (Adger et al. 2007:727). To measure and compare these elements of adaptive capacity, we chose the most reliable and recognized indicators (see Table S2) that were available for the five countries and have been used in previous studies (see, e.g., Schilling et al. 2012).

While vulnerability is the key concept of this paper, we use the concept of resilience when discussing the social implications of climate change. We define resilience as "the ability of a group or community to withstand, recover, and learn from external disturbances" (Schilling et al. 2017:5); in this case, the external disturbance is climate change.

Like all vulnerability assessments, this study has its limitations. Almost all the indicators used in the present study are only available for the national level. This means that variations in the vulnerability within a country cannot be addressed in the present work. Especially for countries with a large geographical size, like Algeria, Libya, and Egypt, the sub-national vulnerabilities are diverse. 
Fig. 2 Vulnerability framework (own representation based on IPCC 2007)

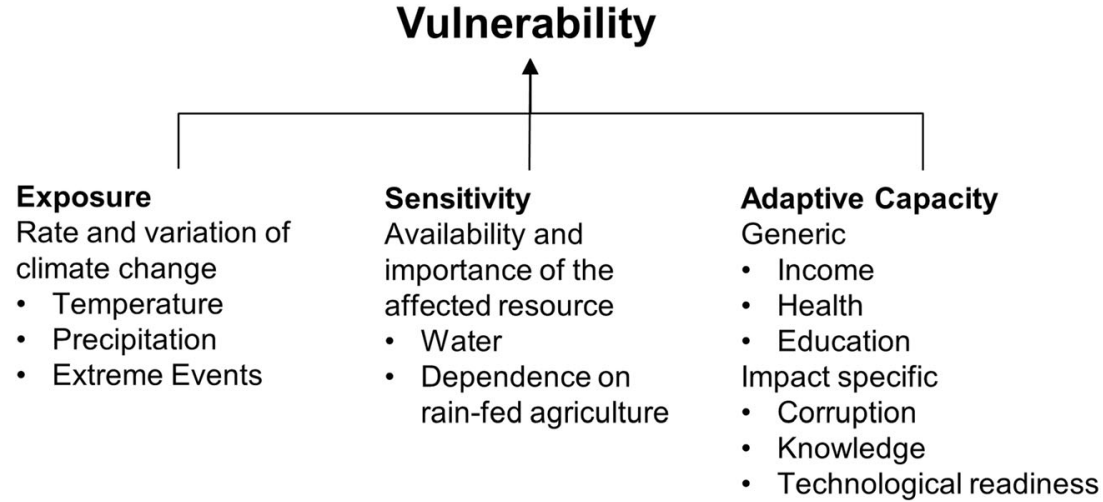

\section{Climate change vulnerability and water resources in North Africa}

\section{Exposure to climate change}

This section focuses on the most important climate variables - temperature and precipitation - and the impact of droughts on water and agriculture as the main livelihood resources in the region.

For almost all parts of North Africa, there was a significant warming trend over the last decades, more pronounced in the summer and with regard to minimum temperatures (see Donat et al. 2013 and Table 1). The warming trend was accompanied by increases in hot nights, hot days, and heat waves and a decrease in cold waves (Elsharkawy and Elmallah 2016; Filahi et al. 2017; Nashwan et al. 2019; Zeroual et al. 2019). Mean precipitation during the wet season, from October to March, has decreased over the last decades, with the strongest decline over the Mediterranean parts of Morocco and Algeria and parts of Libya, whereas a slight increase in precipitation has been observed over Mediterranean Egypt (Hertig and Tramblay 2017; Nashwan et al. 2019; Taibi et al. 2017). For Tunisia, trends are not consistent (Chargui et al. 2018; Fathalli et al. 2019; Kingumbi et al. 2005). Along with the decrease in rainfall during the wet season, wintertime drying has been observed over large parts of western North Africa at least since the 1970s (Hertig and Tramblay 2017; Tramblay et al. 2013a; Zittis 2018). However, some wet years observed since the 2000 s can be attributed to increased climate variability (Donat et al. 2013; Nouaceur and Murărescu 2016). With respect to heavy rainfall events, most parts of North Africa show no significant trends over the last decades (Nashwan et al. 2019; Nasri et al. 2016; Tramblay et al. 2012), while a general increase in drought frequency can be observed in all countries (see Hertig and Tramblay 2017 and Table 1).

Projections under increased greenhouse gas forcing show considerable changes in the mean, the variability, and the extremes for temperature and precipitation over the course of the twenty-first century, making the region one of the major climate change hot spots (Diffenbaugh and Giorgi 2012). With respect to temperature changes, an annual and seasonal warming signal for northern Africa is consistently projected by various general circulation models (GCMs) (e.g.,Collins et al. 2013), regional climate models (RCMs) (e.g., Bucchignani et al. 2018), and statistical projections (e.g., Hertig and Jacobeit 2008). In the Coupled Model Intercomparison Project Phase 5 (CMIP5), GCM ensemble indicates an increase in median temperature of about $4{ }^{\circ} \mathrm{C}$ in the summer and about $2.5^{\circ} \mathrm{C}$ in the winter by the end of
Table 1 Synthesis of past trends in North Africa for the second half of the twentieth century and beginning of the twenty-first century

\begin{tabular}{llllll}
\hline & $\begin{array}{l}\text { Mean } \\
\text { temperature }\end{array}$ & $\begin{array}{l}\text { Extreme temperature/heat } \\
\text { waves }\end{array}$ & $\begin{array}{l}\text { Mean } \\
\text { precipitation }\end{array}$ & $\begin{array}{l}\text { Heavy } \\
\text { rainfall }\end{array}$ & Drought \\
\hline Algeria & ++ & ++ & - & - & ++ \\
Egypt & ++ & +++ & + & No trend & + \\
Libya & ++ & ++ & - & No trend & + \\
Morocco & ++ & ++ & -- & No trend & ++ \\
Tunisia & ++ & ++ & No trend & No trend + \\
\hline
\end{tabular}

Semiquantitative evaluation of temperature changes in absolute terms (small $(+), \leq 0.5{ }^{\circ} \mathrm{C}$; moderate $(++),>$ $0.5^{\circ} \mathrm{C}$ to $\leq 1{ }^{\circ} \mathrm{C}$; strong $(+++),>1{ }^{\circ} \mathrm{C}$ ) and of precipitation changes and drought changes in relative terms (small $(+/-), \leq \pm 10 \%$; moderate (++/-), $> \pm 10 \%$ to $\leq \pm 20 \%$; strong (+++/-), $> \pm 20 \%$ ) 
the twenty-first century under the moderate Representative Concentration Pathways (RCP) 4.5 scenario and about $7{ }^{\circ} \mathrm{C}$ in the summer and $4{ }^{\circ} \mathrm{C}$ in the winter under the more pessimistic RCP8.5 scenario (Christensen et al. 2013). In addition, strong increases in heat waves (as expressed by a strong increase in warm nights, warm days, and warm spell duration) are projected for the whole North Africa region (Lelieveld et al. 2016). With regard to precipitation, the CMIP5 GCM ensemble projects a decrease in rainfall of about $-10 \%$ to $-20 \%$ for large parts of northern Africa (IPCC 2013). The decreasing trend is in general confirmed by dynamical (Ozturk et al. 2018; Tramblay et al. 2018) and statistical downscaling assessments (Dubrovský et al. 2014; Hertig et al. 2013).

With regard to heavy precipitation, Hertig et al. (2013, 2014) found an increasing trend for western North Africa in winter and a decrease for all other seasons. RCM simulations present contrasted projections for Morocco with little robustness (Filahi et al. 2017; Tramblay et al. 2012), an increase in extreme rainfall for Libya in spring and autumn (Gao et al. 2006), and a decrease in rainfall in Mediterranean Egypt (Abiodun et al. 2017). Overall, the projected changes in extreme precipitation for North Africa are rather uncertain, with little agreement between climate models (Tramblay and Somot 2018). CMIP3 and CMIP5 model outputs (Dai and Zhao 2017; Dubrovský et al. 2014) consistently predict an increase in droughts over North Africa, with the strongest changes occurring in the northwest. Likewise, statistical and dynamical downscaling projections show a strong increase in the number and intensity of drought months and the maximum dry-spell length for northern Morocco and Algeria, and small to moderate increases for the Mediterranean parts of Tunisia and Libya (Gao et al. 2006; Hertig and Tramblay 2017). Unlike the projected changes in heavy rainfall events, the climate change signal pointing to an increase in aridity and a reduction of the number of wet days is much stronger (Polade et al. 2017). Table 2 gives a general picture summarizing the anticipated changes.

\section{Impact of climate change on water resources}

The projected precipitation decreases in the southern part of the Mediterranean basin will affect water resources (Lionello and Scarascia 2018). Recently, Tramblay et al. (2018) analyzed the impact of climate change on the water resources of the 46 basins that supply the largest dams and reservoirs in North Africa. They projected a future decline in surface water resources in different climate scenarios, due to a combination of precipitation decreases and evapotranspiration increases along a west-to-east gradient. Some studies based on large-scale hydrological models have also shown a future potential decrease in water resources for the southern Mediterranean region (Prudhomme et al. 2014). Droogers et al. (2012) simulated future water resources for the Maghreb and the Middle East, taking into account both water supply and demand. They obtained a future decrease in water supply by $-12 \%$ on average, coupled with a strong increase in water demand by $+50 \%$.

Indeed, besides the trends in water supply, several studies project a strong increase in water demand for this region due to population growth and economic development, indicating a higher water stress in the future (e.g., Milano et al. 2012). Some studies provide hydrological scenarios on the scale of individual basins in Algeria (e.g., Benhamiche et al. 2014; Elmeddahi et al. 2014), Morocco (e.g., Brouziyne et al. 2018; Tramblay et al. 2013b) and Tunisia (e.g., Bargaoui et al. 2013; Dakhlaoui et al. 2017). Their results indicate a decrease in surface flows that is more pronounced under the RCP8.5 than under the RCP4.5 scenario. Climate model simulations converge toward a decrease in precipitation in spring and to a lesser extent in winter (Tramblay et al. 2016; Tramblay et al. 2018). This decrease in rainfall at the end of winter and spring is responsible for the decline in annual surface runoff. The increase in potential evapotranspiration, linked to the sharp rise in temperatures in this region during the summer period in the future climate, is also responsible for the decline in surface runoff, but more moderately than the decrease in precipitation. The influence of increasing evapotranspiration is most visible in late spring and early fall; for the majority of the basins, an extension of the dry summer season is observed with little to no
Table 2 Synthesis of climate change in North Africa until the end of the twenty-first century

\begin{tabular}{llllll}
\hline & $\begin{array}{l}\text { Mean } \\
\text { temperature }\end{array}$ & $\begin{array}{l}\text { Extreme temperature/heat } \\
\text { waves }\end{array}$ & $\begin{array}{l}\text { Mean } \\
\text { precipitation }\end{array}$ & $\begin{array}{l}\text { Heavy } \\
\text { rainfall }\end{array}$ & Drought \\
\hline Algeria & +++ & +++ & -- & + & +++ \\
Egypt & +++ & +++ & -- & -- & + \\
Libya & +++ & +++ & -- & + & + \\
Morocco & +++ & +++ & -- & + & ++ \\
Tunisia & +++ & +++ & -- & + & + \\
\hline
\end{tabular}

Semiquantitative evaluation of temperature changes in absolute terms ( small $(+), \leq 2{ }^{\circ} \mathrm{C}$; moderate $(++),>2{ }^{\circ} \mathrm{C}$ to $\leq 4{ }^{\circ} \mathrm{C}$; strong $(+++),>4{ }^{\circ} \mathrm{C}$ ) and of precipitation changes and drought changes in relative terms ( small $(+/-), \leq \pm$ $20 \%$; moderate $(++/-),> \pm 20 \%$ to $\leq \pm 40 \%$; strong $(+++/-),> \pm 40 \%)$ 
flow in the rivers during this season. For the mountainous basins with the presence of snow in winter, notably in Morocco in the High Atlas Mountains, the various climatic scenarios point to a sharp decline in snow cover and snowmelt runoff, caused by the strong rise in temperatures and the decrease in precipitation as rain or snow (Marchane et al. 2017).

As a consequence of the decrease in surface runoff, a significant decline in water supply to dams and reservoirs, which are mainly used for irrigation, is expected. In North Africa, these reservoirs are already affected by dam silting, evaporation losses (Boudjadja et al. 2003; Remini et al. 2009), and in some cases deep infiltration losses through the reservoir bed into the aquifers (Leduc et al. 2007). Several studies associate a future decrease in groundwater recharge with the reduction in surface runoff (Benabdallah et al. 2018; Bouchaou et al. 2011; Meddi and Boucefiane 2013); since in semiarid environments, focused infiltration from rivers is the main groundwater recharge process (Leduc et al. 2017). However, until now, North African aquifers have been affected much more by human activities than by climate variability (Leduc et al. 2017; Lezzaik and Milewski 2018). A drop in groundwater levels induced by overexploitation has been reported in the last 50 years in many subregions of the Maghreb countries (Bouchaou et al. 2011; Zkhiri et al. 2019) and has also led to a degradation of water quality in these aquifers. The main cause of the intense pumping of groundwater resources is agricultural demand, together with the significant demand in coastal urban areas with high population densities (Leduc et al. 2017; Lezzaik and Milewski 2018). However, it is now clear that at the current rate of withdrawal, groundwater cannot be considered a long-term resource, given the increased precipitation variability due to climate change in the region (Kuper et al. 2017). Döll (2009) identified North Africa as one of the regions with the highest vulnerability to decreased groundwater resources. In this context, there is a strong need for adaptation strategies to limit the impacts of climate change in this region, through an adaptation of agricultural practices and irrigation strategies (Brouziyne et al. 2018; Seif-Ennasr et al. 2016) and better regulation of well exploitation (Kuper et al. 2017). Several studies agree that these adaptation measures should be implemented at the institutional and local levels to encourage a rational use of water that takes into account both socioeconomic and natural constraints and ensure sustainability (Kuper et al. 2017; Lezzaik and Milewski 2018; Seif-Ennasr et al. 2016). There is also a need for better long-term monitoring of water resources, whereas at the moment, the monitoring network is being reduced (Leduc et al. 2017).

\section{Sensitivity}

In order to assess sensitivity to climate change, this section compares the countries' availability of the affected resource (water) prior to the climate stimuli and the importance of the resource for each country. In all five North African countries, agriculture is by far the largest consumer of withdrawn water, and all countries except Egypt depend almost exclusively on rain as a source of water for agricultural land (Table S1). In terms of gross domestic product, agriculture is most important in Morocco, although $15 \%$ is not very high. It should be noted that the latest data available for Libya is significantly older than for the other countries. In terms of employment, Morocco is most dependent on agriculture and hence most sensitive to climate change.

Figure 3 shows the water situation measured by different indices. Using the Hydrological Water Stress Index (HWSI) and the SWSI (Social Water Scarcity Index), all five countries are regarded as water scarce. This means that according to

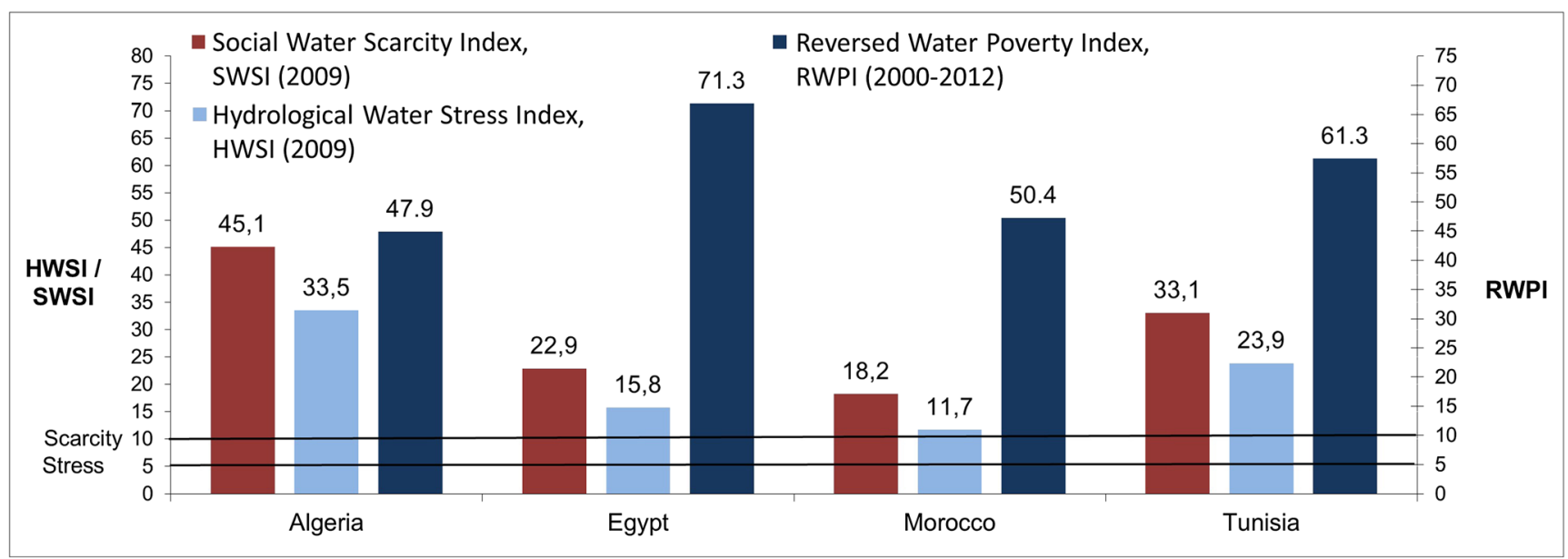

Fig. 3 Sensitivity measured by the water situation, based on three indices (own representation based on FAO 2016; Jemmali 2018; PRB 2017). The Hydrological Water Stress Index (HWSI) measures the number of people in hundreds per one million $\mathrm{m}^{3}$ of available renewable water. The Social Water Scarcity Index (SWSI) is the HWSI divided by the Human
Development Index (see Table S2). The Water Poverty Index (WPI) combines indicators measuring access to water for consumption, cooking, irrigation, and nonagricultural use with water availability measured in $\mathrm{m}^{3}$ per capita per year (for details see Jemmali 2018). For reasons of graphical representation, the WPI has been reversed $(100-$ WPI $=$ RWPI 
these two indices, the water situation has worsened in all five countries since 2009 (see Schilling et al. 2012). Algeria and Tunisia have the highest SWSI and HWSI values, while the values for Morocco and Egypt are significantly lower. Egypt has the highest Reversed Water Poverty Index (RWPI) that is calculated by subtracting the Water Poverty Index (WPI) from 100. Taking all three indices into consideration, the water supply situation is the worst in Algeria, followed by Tunisia, Egypt, and Morocco. On the demand side, the bar diagrams in Fig. 1 show that the highest population growth in both absolute and relative terms is expected to occur in Egypt. Between 2017 and 2050, an additional 70 million people will be living in the country. The second strongest population growth is expected in Algeria, while the growth in Libya, Tunisia, and Morocco is strong in relative rather than absolute terms. In all the countries, strong population growth is highly likely to further aggravate the already scarce water situation.

\section{Adaptive capacity}

Morocco not only has the lowest per capita income but also the highest Gini index and hence the most unequal distribution of income (Table S2). The level of human development is high in Algeria, Libya, and Tunisia and medium in Egypt and Morocco. The under-five child mortality rate is highest in Algeria and Morocco, but the two countries have made significant progress here, as well as in terms of the percentage of the population with access to improved drinking water sources. The latter values were much lower in 2008, when the percentage in Morocco was only 60 (see Schilling et al. 2012). In terms of education, there is still a gap between the other North African countries and Morocco, which has the lowest generic adaptive capacity. Tunisia and Morocco are the least corrupt countries, while Libya is the most corrupt country in all of North Africa (Table S2). Taking all three indicators into account, the impact-specific adaptive capacity is lower in Algeria and Egypt than in Tunisia and Morocco, while not enough data is available to assess the impactspecific adaptive capacity in Libya.

\section{Comparison of vulnerability}

Figure 4 combines key vulnerability indicators of generic adaptive capacity and sensitivity. The gross domestic product (GDP) per capita, the human development index, and the education index were chosen (rather than all six indicators from Table S2) because of a lack of data on two of the indicators for Libya and in order to compare the results to Schilling et al. (2012). For reasons of graphical representation, the indicators representing the sensitivity to climate change have been reversed to insensitivity. The larger the plot area, the greater the generic adaptive capacity (area above the dashed line) and the
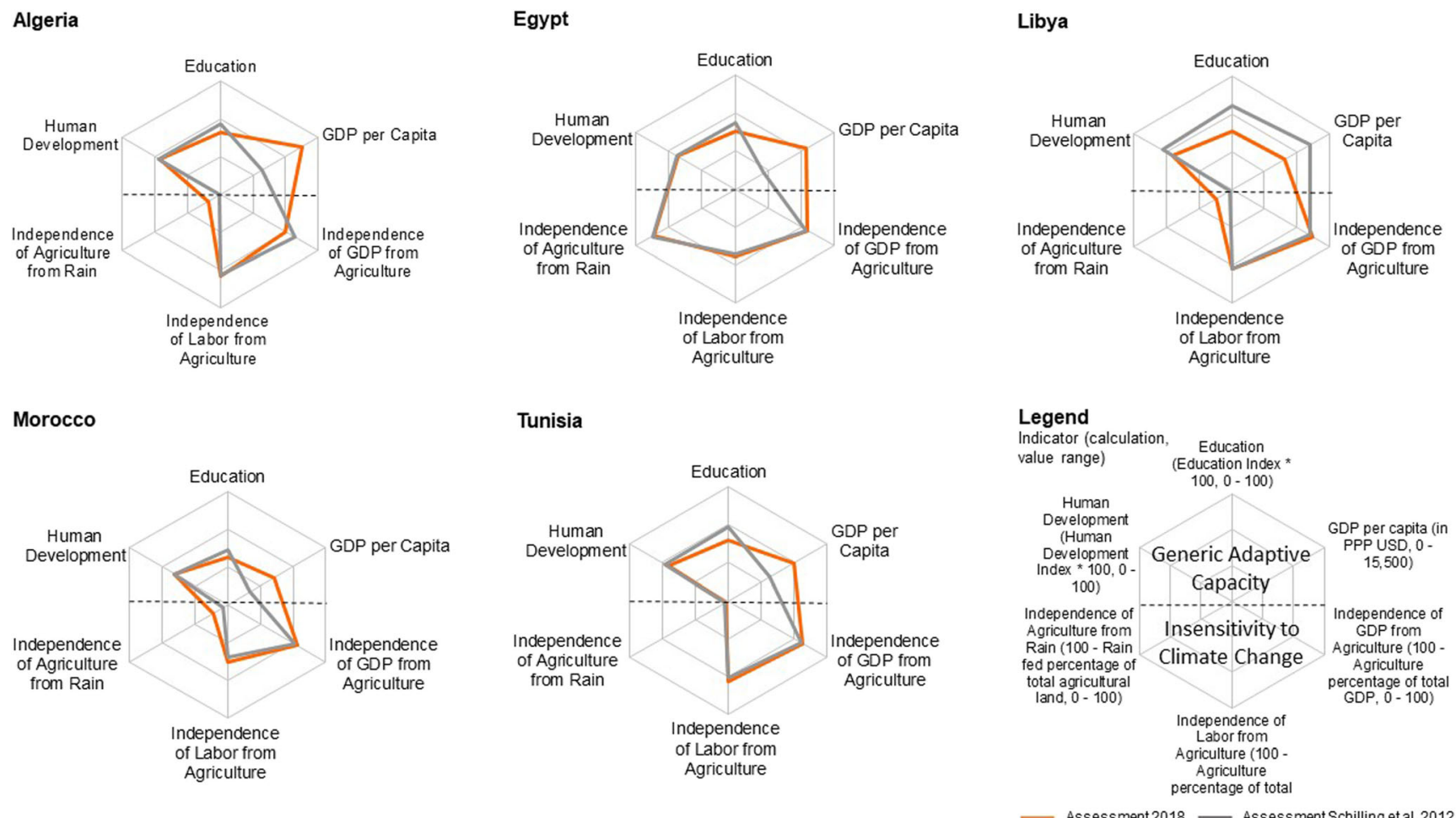

Fig. 4 Generic adaptive capacity and insensitivity to climate change in North Africa (own representation based on CIA 2018; UNDP 2016). The lower three variables (related to agriculture) are taken from Table S1 and reversed for graphical representation. This means dependence on agriculture becomes independence from agriculture. GDP = gross domestic product. PPP USD = purchasing power parity in US dollars 
higher the insensitivity to climate change (area below the dashed line). The orange line shows the assessment based on Tables S1 and S2, while the gray line indicates the values for each indicator as assessed by Schilling et al. (2012). When comparing the orange plot areas, it is obvious that Morocco has the smallest plot area and is hence the most vulnerable to climate change. Algeria and Tunisia have similarly shaped plot areas. In both countries, the importance of rain for agriculture is a key weakness, while a relatively high income level strengthens the adaptive capacity. According to Fig. 4, Egypt has the highest generic adaptive capacity and lowest sensitivity to climate change. When comparing the current situation with the assessment from 2012, increases in income can be observed in all countries but Libya, where the generic adaptive capacity shows a declining trend.

Overall, all North African countries are exposed to strong climate change, with Morocco and Algeria particularly at risk (see Sect. 3.1). The sensitivity to climate change is highest in Algeria, Tunisia, and Egypt, while water is also scarce in Morocco. In Libya the sensitivity is unclear due to a lack of data. Algeria has the highest generic adaptive capacity but also the lowest impact-specific adaptive capacity. Taking all the elements of vulnerability into consideration, Algeria is the most vulnerable country. In the assessment by Schilling et al. (2012), this was Morocco. The results of the present study are in line with earlier findings by Waha et al. (2017:1627), who see Algeria as one of the countries in North Africa that will become "global hot spots for drought by the end of the twenty-first century." In contrast, Ahmadalipour and Moradkhani (2018) find Algeria to be less vulnerable to drought, in comparison with all countries on the African continent.

\section{Social implications of climate change}

The social implications of climate change depend on the vulnerability of each country and are hence location-specific. The following sections highlight some of the key implications for food production and conflict in North Africa.

\section{Food production}

Climate change will negatively affect the largely rain-fed agricultural production in North Africa (Waha et al. 2017). For the central northern region of Algeria, a reduction in durum wheat production of between $22 \%$ and $40 \%$ is projected for the period from 2071 to 2100 compared to the 1980-2009 baseline period using the IPCC A1B scenario (Chourghal et al. 2016). The extent of the reduction depends on whether prescribed or dynamic sowing is assumed. For the eastern high plains of Algeria, the yield loss is expected to be lower. In Egypt, wheat yields are projected to decline due to climate change, despite improvements obtained through crop intensification and expansion of irrigated areas (Asseng et al. 2018). In addition to losses caused by changes in temperature, rainfall, and extreme $\mathrm{CO}_{2}$ concentrations, a sea level rise of $1 \mathrm{~m}$ is projected to lead to a loss of one-third of the current agricultural land in the Nile Delta (El-Nahry and Doluschitz 2010). A simulation by Fader et al. (2016) suggests that Libya will be unable to meet its irrigation water requirements toward the end of the century, even when the most optimistic scenario of climate change and irrigation technologies are considered (for adaptation options see also Harmanny and Malek 2019). For Morocco, yield losses of around 10\% between 2003 and 2050 are projected for the major crop-producing areas under the IPCC A2 scenario without considering a $\mathrm{CO}_{2}$ fertilization effect. Even when including this effect and using the optimistic B2 scenario, the majority of areas in Morocco's breadbasket will see decreases in yield (Ouraich and Tyner 2018). For Tunisia, Zouabi and Peridy (2015) show that a $1 \%$ decrease in precipitation leads to $0.79 \%$ decrease in the production of cereals.

All North African countries produce and import cereals (wheat, barley, maize, and others). While Egypt is by far the largest producer and importer, Morocco has the highest and Libya the lowest per capita production. Libya also the highest dependency on cereal imports (Table S3).

\section{Conflict}

As North African countries are strongly dependent on agriculture for gross domestic product and particularly employment (see Sect. 3.3), climate change can be expected to undermine food security, economic security, resilience, and overall livelihood prospects in the region (see also Waha et al. 2017). This is even more significant given that strong population growth (Fig.1) will increase the demand for food and income opportunities. However, the widening gap between the supply and demand of critical resources is not sufficient to draw direct climate-conflict links. The wide body of literature has shown that links between climate and conflict variables are indirect and complex (Adams et al. 2018; Buhaug 2015; Mach et al. 2019; Scheffran et al. 2012; Schleussner et al. 2016). In North Africa, climate change is expected to negatively impact agricultural production (Sect. 4.1), which in turn could contribute to rising food prices and food insecurity, leading to protests and riots against the government (see also Scheffran et al. 2019; Waha et al. 2017). This pathway was prominently discussed as part of the so-called Arab Spring of 2011, when protests and riots led to political change in Tunisia, Libya, and Egypt (Sottilotta 2015). Demonstrations also took place in Morocco and Algeria (Bayat 2013). Some authors have called the Arab Spring a "textbook example" (Johnstone and Mazo 2011:11; see also Werrell and Femia 2013) of how climate change aggravated food prices and food insecurity, thus 
resulting in riots and violence. Another study suggests that drought and crop failure in China led the country to strongly increase its wheat imports, which in turn contributed to a doubling of global wheat prices, triggering riots in Egypt (Sternberg 2012). The majority of studies identify sharply increasing food prices and living costs as drivers of the Arab Spring (e.g., Johnstone and Mazo 2011; Sternberg 2012; Werrell and Femia 2013). However, several studies attribute these rising costs to government policies and government failures rather than climate change and drought (e.g., AlShammari and Willoughby 2019; Devarajan and Ianchovichina 2018).

Violent conflicts in the region are mainly driven by political motives. The key actors in attacks on state governments are terrorist groups such as the so-called Islamic State and affiliates of Al-Qaeda (see overview in Table S4). Algeria and Libya have experienced the highest number of violent conflicts in the recent past (Table S4). Although climate change has not been identified as a major driver of conflict, there is a growing body of literature suggesting that droughts, especially in very poor countries, increase the likelihood of sustained violence for groups dependent on agricultural, and those experiencing political exclusion (Brzoska 2018; von Uexkull et al. 2016). Furthermore, studies on East Africa have found higher rates of insurgency in abnormally dry conditions (Raleigh and Kniveton 2012). For North Africa, however, there have not been any studies suggesting that food and economic insecurity make people more vulnerable to recruitment by terrorist groups.

All 24 violent conflicts recorded in North Africa between 2008 and 2017 are internal (Table S4). Two of these conflicts are classified as "internationalized internal," meaning that the conflict is between the state government and internal opposition groups with intervention from at least one other state (UCDP/PRIO 2018). While there is a potential for international political tensions and disputes between the riparian states of the Nile river, for example, when Egypt feels threatened by increasing water demand in upstream countries like Ethiopia, shared international water bodies are generally a source of cooperation rather than conflict (Link et al. 2016; Wolf 2007).

\section{Conclusions}

The aim of this paper was to assess and compare the climate change vulnerability of Algeria, Egypt, Libya, Morocco, and Tunisia, with an emphasis on water resources, and to link it to its social implications. In terms of exposure to mean and extreme temperature rise, many similarities exist between the North African countries. Droughts will become more severe, with the strongest increases expected for Morocco and Algeria. While the largest uncertainties are related to projections of heavy rainfall events, climate change will negatively affect the already scarce water situation in all countries. The sensitivity to these changes is highest in Algeria, Tunisia, and Egypt. For Libya, a lack of data or outdated data poses a challenge for the assessment of the sensitivity and adaptive capacity. Algeria has the highest generic adaptive capacity but also the lowest impact-specific adaptive capacity. Based on the indicators analyzed in the present work, Algeria appears to be the most vulnerable country, followed by Morocco.

Social unrest such as the Arab Spring is partly caused by the fact that the basic needs of the population are not met. As the population of the region and hence the demand for food and water increases, it will become increasingly difficult to satisfy these needs. Climate change further aggravates this situation through its negative effects on the supply of food and water. Thus, climate change may become an indirect driver of social instability. The violent conflicts in the region are all internal and mostly driven by terrorist groups. The degree to which climate change affects these conflicts is currently unclear and further research is needed. It is, however, certain that violent conflict undermines the adaptive capacity and thus the resilience of a country, as the case of Libya shows.

For all North African countries and particularly Algeria and Morocco, it is important to reduce economic and livelihood dependence on rain-fed agriculture, strengthen sustainable land use practices, and increase the adaptive capacity. Since all North African countries face similar climate change exposure, increased regional cooperation will be useful through the sharing of good practices to mitigate the impacts of climate change. For researchers, a promising area of study is the development of vulnerability indicators that capture the subnational level and allow for intra- and inter-country vulnerability comparisons at the local level.

Acknowledgments We would like to thank the three external reviewers as well as Maria Carmen Llasat and Christopher Reyer for their helpful comments and suggestions. We would also like to thank Mara Wagner for assisting in the data preparation.

Funding information Open Access funding provided by Projekt DEAL. The overall work is supported and funded by the University of KoblenzLandau, the Peace Academy Rhineland-Palatinate, the Federal Ministry of Education and Research (BMBF) under the project 'SaliDraa 2' (01UU1906), the German Research Foundation (DFG) under contract HE 6186/4-1 and under project number 408057478 and the University of Hamburg's Cluster of Excellence 'Climate, Climatic Change and Society - CLICCS', funded by the DFG.

Open Access This article is licensed under a Creative Commons Attribution 4.0 International License, which permits use, sharing, adaptation, distribution and reproduction in any medium or format, as long as you give appropriate credit to the original author(s) and the source, provide a link to the Creative Commons licence, and indicate if changes were made. The images or other third party material in this article are included in the article's Creative Commons licence, unless indicated otherwise in a credit line to the material. If material is not included in the article's Creative Commons licence and your intended use is not 
permitted by statutory regulation or exceeds the permitted use, you will need to obtain permission directly from the copyright holder. To view a copy of this licence, visit http://creativecommons.org/licenses/by/4.0/.

\section{References}

Abiodun BJ, Adegoke J, Abatan AA, Ibe CA, Egbebiyi TS, Engelbrecht F, Pinto I (2017) Potential impacts of climate change on extreme precipitation over four African coastal cities. Clim Chang 143:399 413. https://doi.org/10.1007/s10584-017-2001-5

Adams C, Ide T, Barnett J, Detges A (2018) Sampling bias in climateconflict research. Nat Clim Chang 8:200-203. https://doi.org/10. 1038/s41558-018-0068-2

Adger WN, Agrawala S, Mirza MMQ, Conde C, O'Brien K, Pulhin J, Pulwarty R, Smit B, Takahashi K (2007) Assessment of adaptation practices, options, constraints and capacity. In: M.L. Parry ML, Canziani OF, Palutikof JP, van der Linden PJ, Hanson CE (eds) Climate change 2007: impacts, adaptation and vulnerability. Contribution of Working Group II to the Fourth Assessment Report of the Intergovernmental Panel on Climate Change. Cambridge University Press, Cambridge, pp 717-743

Ahmadalipour A, Moradkhani H (2018) Multi-dimensional assessment of drought vulnerability in Africa: 1960-2100. Sci Total Environ 644:520-535. https://doi.org/10.1016/j.scitotenv.2018.07.023

Alboghdady M, El-Hendawy SE (2016) Economic impacts of climate change and variability on agricultural production in the Middle East and North Africa region. Int J Clim Change Str 8:463-472. https://doi.org/10.1108/ijccsm-07-2015-0100

Al-Shammari N, Willoughby J (2019) Determinants of political instability across Arab spring countries. Mediterr Politics 24:196-217. https://doi.org/10.1080/13629395.2017.1389349

Asseng S, Kheir AMS, Kassie BT, Hoogenboom G, Abdelaal AIN, Haman DZ, Ruane AC (2018) Can Egypt become self-sufficient in wheat? Environ Res Lett 13:1-11. https://doi.org/10.1088/17489326/aada50

Bargaoui Z, Tramblay Y, Lawin EA, Servat E (2013) Seasonal precipitation variability in regional climate simulations over northern basins of Tunisia. Int J Climatol 34:235-248. https://doi.org/10.1002/joc. 3683

Bayat A (2013) The Arab Spring and its surprises. Dev Change 44:587601. https://doi.org/10.1111/dech.12030

Benabdallah S, Mairech H, Hummel FM (2018) Assessing the impacts of climate change on groundwater recharge for the Chiba Basin in Tunisia. In: Calvache ML, Duque C, Pulido-Velazquez D (eds) Groundwater and global change in the western Mediterranean area. Springer International Publishing, Cham, pp 27-33

Benhamiche N, Madani K, Laignel B (2014) Impact of climate changes on water resources in Algeria. In: Behnassi M, Syomiti Muteng'e M, Ramachandran G, Shelat KN (eds) Vulnerability of agriculture, water and fisheries to climate change: toward sustainable adaptation strategies. Springer Netherlands, Dordrecht, pp 193-205

Bouchaou L, Tagma T, Boutaleb S, Hssaisoune M, El Abidine El Morjani Z (2011) Climate change and its impacts on groundwater resources in Morocco: the case of the Souss-Massa basin. In: Treidel H, Martin-Bordes JL, Gurdak JJ (eds) Climate change effects on groundwater resources: a global synthesis of findings and recommendations. CRC Press, London, pp 129-142

Boudjadja A, Messahel M, Pauc H (2003) Ressources hydriques en Algérie du Nord. Revue Sci L'eau 16:285-304. https://doi.org/10. 7202/705508ar

Brouziyne Y, Abouabdillah A, Hirich A, Bouabid R, Zaaboul R, Benaabidate L (2018) Modeling sustainable adaptation strategies toward a climate-smart agriculture in a Mediterranean watershed under projected climate change scenarios. Agric Syst 162:154 163. https://doi.org/10.1016/j.agsy.2018.01.024

Brzoska M (2018) Weather extremes, disasters, and collective violence: conditions, mechanisms, and disaster-related policies in recent research. Curr Clim Change Rep 4:320-329. https://doi.org/10.1007/ s40641-018-0117-y

Bucchignani E, Mercogliano P, Panitz H-J, Montesarchio M (2018) Climate change projections for the Middle East-North Africa domain with COSMO-CLM at different spatial resolutions. Ad Clim Change Res 9:66-80. https://doi.org/10.1016/j.accre.2018.01.004

Buhaug H (2015) Climate-conflict research: some reflections on the way forward. WIRES - Clim Change 6:269-275. https://doi.org/10. $1002 /$ wcc. 336

Chargui S, Jaberi A, Cudennec C, Lachaal F, Calvez R, Slimani M (2018) Statistical detection and no-detection of rainfall change trends and breaks in semiarid Tunisia-50+ years over the Merguellil agrohydro-climatic reference basin. Arab J Geosci 11:675-614. https:// doi.org/10.1007/s12517-018-4001-9

Chourghal N, Lhomme JP, Huard F, Aidaoui A (2016) Climate change in Algeria and its impact on durum wheat. Reg Environ Chang 16: 1623-1634. https://doi.org/10.1007/s10113-015-0889-8

Christensen JH, Krishna Kumar K, Aldrian E, An S-I, Cavalcanti IFA, de Castro M, Dong W, Goswami P, Hall A, Kanyanga JK, Kitoh A, Kossin J, Lau N-C, Renwick J, Stephenson DB, Xie S-P, Zhou T (2013) Climate phenomena and their relevance for future regional climate change. In: Stocker TF, D. Qin, G.-K. Plattner, M. Tignor, S.K. Allen, J. Boschung, A. Nauels, Y. Xia, V. Bex and P.M. Midgley (eds) Climate change 2013: the physical science basis. Contribution of Working Group I to the Fifth Assessment Report of the Intergovernmental Panel on Climate Change. Cambridge University Press, Cambridge, pp 1217-1310

CIA (2018) CIA world factbook. https://www.cia.gov/library/ publications/the-world-factbook/. Accessed 2 May 2018

Collins M, Knutti R, Arblaster J, Dufresne J-L, Fichefet T, Friedlingstein P, Gao X, Gutowski WJ, Johns T, Krinner G, Shongwe M, Tebaldi C, Weaver AJ, Wehner M (2013) Long-term climate change: projections, commitments and irreversibility. In: Stocker TF, D. Qin, G.-K. Plattner, M. Tignor, S.K. Allen, J. Boschung, A. Nauels, Y. Xia, V. Bex and P.M. Midgley (eds) Climate change 2013: the physical science basis. Contribution of Working Group I to the Fifth Assessment Report of the Intergovernmental Panel on Climate Change. Cambridge University Press, Cambridge, pp 1029-1136

Cook BI, Anchukaitis KJ, Touchan R, Meko DM, Cook ER (2016) Spatiotemporal drought variability in the Mediterranean over the last 900 years. J Geophys Res-Atmos 121:2060-2074. https://doi.org/ 10.1002/2015JD023929

Dai A, Zhao T (2017) Uncertainties in historical changes and future projections of drought. Part I: estimates of historical drought changes. Clim Chang 144:519-533. https://doi.org/10.1007/s10584-016$1705-2$

Dakhlaoui H, Ruelland D, Tramblay Y, Bargaoui Z (2017) Evaluating the robustness of conceptual rainfall-runoff models under climate variability in northern Tunisia. J Hydrol 550:201-217. https://doi.org/ 10.1016/j.jhydrol.2017.04.032

Devarajan S, Ianchovichina E (2018) A broken social contract, not high inequality, led to the Arab Spring. Rev Income Wealth 64:5-25. https://doi.org/10.1111/roiw.12288

Diffenbaugh NS, Giorgi F (2012) Climate change hotspots in the CMIP5 global climate model ensemble. Clim Chang 114:813-822. https:// doi.org/10.1007/s10584-012-0570-x

Döll P (2009) Vulnerability to the impact of climate change on renewable groundwater resources: a global-scale assessment. Environ Res Lett 4:1-12. https://doi.org/10.1088/1748-9326/4/3/035006

Donat MG, Peterson TC, Brunet M, King AD, Almazroui M, Kolli RK, Boucherf D, Al-Mulla Anwar Y, Nour Abdourahman Y, Aly Ahmed 
A, Nada Tamer Ali A, Semawi Muhammad M, Al Dashti Hasan A, Salhab Tarek G, El Fadli KI, Muftah Mohamed K, Dah Eida S, Badi W, Driouech F, El Rhaz K, Abubaker Mohammed JY, Ghulam Ayman S, Erayah Amani S, Mansour Maher B, Alabdouli Waleed O, Al Dhanhani Jemie S, Al Shekaili Majed N (2013) Changes in extreme temperature and precipitation in the Arab region: long-term trends and variability related to ENSO and NAO. Int J Climatol 34: 581-592. https://doi.org/10.1002/joc.3707

Droogers P, Immerzeel WW, Terink W, Hoogeveen J, Bierkens MFP, van Beek LPH, Debele B (2012) Water resources trends in Middle East and North Africa towards 2050. Hydrol Earth Syst Sci 16:31013114. https://doi.org/10.5194/hess-16-3101-2012

Dubrovský M, Hayes M, Duce P, Trnka M, Svoboda M, Zara P (2014) Multi-GCM projections of future drought and climate variability indicators for the Mediterranean region. Reg Environ Chang 14: 1907-1919. https://doi.org/10.1007/s10113-013-0562-z

Elmeddahi Y, Issaadi A, Mahmoudi H, Tahar Abbes M, Goosen MFA (2014) Effect of climate change on water resources of the Algerian Middle Cheliff basin. Desalin Water Treat 52:2073-2081. https:// doi.org/10.1080/19443994.2013.831777

El-Nahry AH, Doluschitz R (2010) Climate change and its impacts on the coastal zone of the Nile Delta, Egypt. Environ Earth Sci 59:14971506. https://doi.org/10.1007/s12665-009-0135-0

Elsharkawy SG, Elmallah ES (2016) Spatiotemporal investigation of long-term seasonal temperature variability in Libya. Atmos Res 178-179:535-549. https://doi.org/10.1016/j.atmosres.2016.05.004

ESA (2015a) Climate change initiative project. https://maps.elie.ucl.ac. be/CCI/viewer/download.php. Accessed 6 June 2018

ESA (2015b) Land cover map. https://maps.elie.ucl.ac.be/CCI/viewer/ download.php. Accessed 6 June 2018

Fader M, Shi S, von Bloh W, Bondeau A, Cramer W (2016) Mediterranean irrigation under climate change: more efficient irrigation needed to compensate for increases in irrigation water requirements. Hydrol Earth Syst Sci 20:953-973. https://doi.org/10. 5194/hess-20-953-2016

FAO (2016) AQUASTAT - Main Database. http://www.fao.org/nr/water/ aquastat/data/query/index.html?lang=en. Accessed 20 August 2018

Fathalli B, Pohl B, Castel T, Safi MJ (2019) Errors and uncertainties in regional climate simulations of rainfall variability over Tunisia: a multi-model and multi-member approach. Clim Dyn 52:335-361. https://doi.org/10.1007/s00382-018-4150-2

Filahi S, Tramblay Y, Mouhir L, Diaconescu EP (2017) Projected changes in temperature and precipitation indices in Morocco from highresolution regional climate models. Int J Climatol 37:4846-4863. https://doi.org/10.1002/joc.5127

Gao X, Pal JS, Giorgi F (2006) Projected changes in mean and extreme precipitation over the Mediterranean region from a high resolution double nested RCM simulation. Geophys Res Lett 33:1-4. https:// doi.org/10.1029/2005GL024954

Haddadin MJ (2001) Water scarcity impacts and potential conflicts in the MENA region. Water Int 26:460-470. https://doi.org/10.1080/ 02508060108686947

Harmanny KS, Malek Ž (2019) Adaptations in irrigated agriculture in the Mediterranean region: an overview and spatial analysis of implemented strategies. Reg Environ Chang 19:1401-1416. https://doi. org/10.1007/s10113-019-01494-8

Hertig E, Jacobeit J (2008) Downscaling future climate change: temperature scenarios for the Mediterranean area. Glob Planet Change 63: 127-131. https://doi.org/10.1016/j.gloplacha.2007.09.003

Hertig E, Tramblay Y (2017) Regional downscaling of Mediterranean droughts under past and future climatic conditions. Glob Planet Change 151:36-48. https://doi.org/10.1016/j.gloplacha.2016.10. 015

Hertig E, Seubert S, Paxian A, Vogt G, Paeth H, Jacobeit J (2013) Changes of total versus extreme precipitation and dry periods until the end of the twenty-first century: statistical assessments for the
Mediterranean area. Theor Appl Climatol 111:1-20. https://doi. org/10.1007/s00704-012-0639-5

Hertig E, Seubert S, Paxian A, Vogt G, Paeth H, Jacobeit J (2014) Statistical modelling of extreme precipitation indices for the Mediterranean area under future climate change. Int J Climatol 34: 1132-1156. https://doi.org/10.1002/joc.3751

IPCC (2007) Climate change 2007: climate change impacts, adaptation and vulnerability. Cambridge University Press, Geneva

IPCC (2013) Annex I: atlas of global and regional climate projections. In: Stocker TF, D. Qin, G.-K. Plattner, M. Tignor, S.K. Allen, J. Boschung, A. Nauels, Y. Xia, V. Bex and P.M. Midgley (eds) Climate change 2013: the physical science basis. Contribution of Working Group I to the Fifth Assessment Report of the Intergovernmental Panel on Climate Change. Cambridge University Press, Cambridge, pp 1311-1310

Jemmali H (2018) Water poverty in Africa: a review and synthesis of issues, potentials, and policy implications. Soc Indic Res 136:335358. https://doi.org/10.1007/s11205-016-1521-0

Johnstone S, Mazo J (2011) Global warming and the Arab Spring. Survival 53:11-17. https://doi.org/10.1080/00396338.2011.571006

Kingumbi A, Bargaoui Z, Hubert P (2005) Investigations sur la variabilite pluviometrique en Tunisie centrale. Hydro S J 50:1-508. https://doi. org/10.1623/hysj.50.3.493.65027

Kuper M, Amichi H, Mayaux P-L (2017) Groundwater use in North Africa as a cautionary tale for climate change adaptation. Water Int 42:725-740. https://doi.org/10.1080/02508060.2017.1351058

Leduc C, Ammar SB, Favreau G, Beji R, Virrion R, Lacombe G, Tarhouni J, Aouadi C, Chelli BZ, Jebnoun N, Oi M, Michelot JL, Zouari K (2007) Impacts of hydrological changes in the Mediterranean zone: environmental modifications and rural development in the Merguellil catchment, central Tunisia. Hydro Sci J 52: 1162-1178. https://doi.org/10.1623/hysj.52.6.1162

Leduc C, Pulido-Bosch A, Remini B (2017) Anthropization of groundwater resources in the Mediterranean region: processes and challenges. Hydrogeol J 25:1529-1547. https://doi.org/10.1007/ s10040-017-1572-6

Lelieveld J, Proestos Y, Hadjinicolaou P, Tanarhte M, Tyrlis E, Zittis G (2016) Strongly increasing heat extremes in the Middle East and North Africa (MENA) in the 21st century. Clim Chang 137:245260. https://doi.org/10.1007/s10584-016-1665-6

Lezzaik K, Milewski A (2018) A quantitative assessment of groundwater resources in the Middle East and North Africa region. Hydrogeol J 26:251-266. https://doi.org/10.1007/s10040-017-1646-5

Link MP, Scheffran J, Ide T (2016) Conflict and cooperation in the watersecurity nexus: a global comparative analysis of river basins under climate change. WIRES Water 3:495-515. https://doi.org/10.1002/ wat2.1151

Lionello P, Scarascia L (2018) The relation between climate change in the Mediterranean region and global warming. Reg Environ Chang 18: 1481-1493. https://doi.org/10.1007/s10113-018-1290-1

Mach KJ, Kraan CM, Adger WN, Buhaug H, Burke M, Fearon JD, Field CB, Hendrix CS, Maystadt J-F, O'Loughlin J, Roessler P, Scheffran J, Schultz KA, von Uexkull N (2019) Climate as a risk factor for armed conflict. Nature 571:193-197. https://doi.org/10.1038/ s41586-019-1300-6

Marchane A, Tramblay Y, Hanich L, Ruelland D, Jarlan L (2017) Climate change impacts on surface water resources in the Rheraya catchment (High Atlas, Morocco). Hydrolog Sci J 62:979-995. https://doi.org/ $10.1080 / 02626667.2017 .1283042$

Meddi M, Boucefiane A (2013) Climate change impact on groundwater in Cheliff-Zahrez basin (Algeria). APCBEE Procedia 5:446-450. https://doi.org/10.1016/j.apcbee.2013.05.077

Milano M, Ruelland D, Fernandez S, Dezetter A, Fabre J, Servat E (2012) Facing climatic and anthropogenic changes in the Mediterranean basin: what will be the medium-term impact on water stress? Compt Rendus Geosci 344:432-440. https://doi.org/10.1016/j.crte.2012.07.006 
Nashwan MS, Shahid S, Abd Rahim N (2019) Unidirectional trends in annual and seasonal climate and extremes in Egypt. Theor Appl Climatol 136:457-473. https://doi.org/10.1007/s00704-018-2498-1

Nasri B, Tramblay Y, Adlouni SE, Hertig E, Ouarda TBMJ (2016) Atmospheric predictors for annual maximum precipitation in North Africa. J Appl Meteorol Climatol 55:1063-1076. https://doi. org/10.1175/jamc-d-14-0122.1

Nouaceur Z, Murărescu O (2016) Rainfall variability and trend analysis of annual rainfall in North Africa. J Atmos Sci 2016:1-12. https:// doi.org/10.1155/2016/7230450

Ouraich I, Tyner WE (2018) Moroccan agriculture, climate change, and the Moroccan green plan: a CGE analysis. Afr J Agric Resour Econ 13:307-330. https://doi.org/10.22004/ag.econ.284990

Ozturk T, Turp M, Türkes M, Kurnaz M (2018) Future projections of temperature and precipitation climatology for CORDEX-MENA domain using RegCM4.4. Atmos Res 206:87-107. https://doi.org/ 10.1016/j.atmosres.2018.02.009

Polade SD, Gershunov A, Cayan DR, Dettinger MD, Pierce DW (2017) Precipitation in a warming world: assessing projected hydro-climate changes in California and other Mediterranean climate regions. Sci Rep 7:10783. https://doi.org/10.1038/s41598-017-11285-y

PRB (2017) 2017 world population data sheet. USAID. https://www.prb. org/2017-world-population-data-sheet/. Accessed 3 December 2017

Prudhomme C, Giuntoli I, Robinson EL, Clark DB, Arnell NW, Dankers R, Fekete BM, Franssen W, Gerten D, Gosling SN, Hagemann S, Hannah DM, Kim H, Masaki Y, Satoh Y, Stacke T, Wada Y, Wisser D (2014) Hydrological droughts in the 21st century, hotspots and uncertainties from a global multimodel ensemble experiment. Proc Natl Acad Sci 111:3262-3267

Raleigh C, Kniveton D (2012) Come rain or shine: an analysis of conflict and climate variability in East Africa. J Peace Res 49:51-64. https:// doi.org/10.1177/0022343311427754

Remini B, Leduc C, Hallouche W (2009) Évolution des grands barrages en régions arides : quelques exemples algériens. Sci Change Planet 20:96-103. https://doi.org/10.1684/sec.2009.0172

Scheffran J, Brzoska M, Kominek J, Link PM, Schilling J (2012) Climate change and violent conflict. Science 336:869-871. https://doi.org/ 10.1126/science. 1221339

Scheffran J, Link M, Schilling J (2019) Climate and conflict in Africa. In: Claussen M (ed) Oxford research encyclopedia. Oxford University press, New York online only

Schilling J, Krause L (2018) Climate change and conflict in northern Africa. In: Wohl E (ed) Oxford bibliographies in environmental science. Oxford University press, New York online only

Schilling J, Freier KP, Hertig E, Scheffran J (2012) Climate change, vulnerability and adaptation in North Africa with focus on Morocco. Agric Ecosyst Environ 156:12-26. https://doi.org/10. 1016/j.agee.2012.04.021

Schilling J, Nash SL, Ide T, Scheffran J, Froese R, von Prondzinski P (2017) Resilience and environmental security: towards joint application in peacebuilding. Glob Change Peace Secur 29:107-127. https://doi.org/10.1080/14781158.2017.1305347

Schleussner C-F, Donges JF, Donner RV, Schellnhuber HJ (2016) Armedconflict risks enhanced by climate-related disasters in ethnically fractionalized countries. Proc Natl Acad Sci 113:9216-9221. https://doi.org/10.1073/pnas.1601611113

Schmitz C, Lotze-Campen H, Gerten D, Dietrich JP, Bodirsky B, Biewald A, Popp A (2013) Blue water scarcity and the economic impacts of future agricultural trade and demand. Water Resour Res 49:36013617. https://doi.org/10.1002/wrcr.20188

Seif-Ennasr M, Zaaboul R, Hirich A, Caroletti GN, Bouchaou L, El Morjani ZEA, Beraaouz EH, McDonnell RA, Choukr-Allah R (2016) Climate change and adaptive water management measures in Chtouka Ait Baha region (Morocco). Sci Total Environ 573:862 875. https://doi.org/10.1016/j.scitotenv.2016.08.170
Sottilotta CE (2015) Political risk assessment and the Arab spring: what can we learn? Thunderbird Int Bus Rev 57:379-390. https://doi.org/ $10.1002 /$ tie. 21689

Sternberg T (2012) Chinese drought, bread and the Arab spring. Appl Geogr 34:519-524. https://doi.org/10.1016/j.apgeog.2012.02.004

Taibi S, Meddi M, Mahé G, Assani A (2017) Relationships between atmospheric circulation indices and rainfall in Northern Algeria and comparison of observed and RCM-generated rainfall. Theor Appl Climatol 127:241-257. https://doi.org/10.1007/s00704-0151626-4

Thomas RJ (2008) Opportunities to reduce the vulnerability of dryland farmers in central and West Asia and North Africa to climate change. Agric Ecosyst Environ 126:36-45. https://doi.org/10.1016/j.agee. 2008.01.011

Tramblay Y, Somot S (2018) Future evolution of extreme precipitation in the Mediterranean. Clim Chang 151:289-302. https://doi.org/10. 1007/s10584-018-2300-5

Tramblay Y, Badi W, Driouech F, El Adlouni S, Neppel L, Servat E (2012) Climate change impacts on extreme precipitation in Morocco. Glob Planet Change 82-83:104-114. https://doi.org/10. 1016/j.gloplacha.2011.12.002

Tramblay Y, El Adlouni S, Servat E (2013a) Trends and variability in extreme precipitation indices over Maghreb countries. Nat Hazards Earth Syst Sci 13:3235-3248. https://doi.org/10.5194/nhess-133235-2013

Tramblay Y, Ruelland D, Somot S, Bouaicha R, Servat E (2013b) Highresolution Med-CORDEX regional climate model simulations for hydrological impact studies: a first evaluation of the ALADINclimate model in Morocco. Hydrol Earth Syst Sci 17:3721-3739. https://doi.org/10.5194/hess-17-3721-2013

Tramblay Y, Ruelland D, Hanich L, Dakhlaoui H (2016) Hydrological impacts of climate change in north African countries. In: Thiébault S, Moatti J-P (eds) The Mediterranean region under climate change: a scientific update. IRD, Marseille, pp 295-302

Tramblay Y, Jarlan L, Hanich L, Somot S (2018) Future scenarios of surface water resources availability in North African dams. Sustain Water Resour Manag 32:1291-1306. https://doi.org/10.1007/ s11269-017-1870-8

UCDP/PRIO (2018) UCDP/PRIO Armed Conflict Dataset Codebook Version 18.1. Uppsala Conflict Data Program. http://ucdp.uu.se/ downloads/. Accessed 26 April 2019

UNDP (2016) Human development report 2016. Communications Development Incorporated, New York

von Uexkull N, Croicu M, Fjelde H, Buhaug H (2016) Civil conflict sensitivity to growing-season drought. Proc Natl Acad Sci 113: 12391-12396. https://doi.org/10.1073/pnas.1607542113

Waha K, Krummenauer L, Adams S, Aich V, Baarsch F, Coumou D, Fader M, Hoff H, Jobbins G, Marcus R, Mengel M, Otto IM, Perrette M, Rocha M, Robinson A, Schleussner CF (2017) Climate change impacts in the Middle East and Northern Africa (MENA) region and their implications for vulnerable population groups. Reg Environ Chang 17:1623-1638. https://doi.org/10. 1007/s10113-017-1144-2

Werrell C, Femia F (2013) The Arab Spring and climate change. Center for American Progress, Washington

Wolf AT (2007) Shared waters: conflict and cooperation. Annu Rev Environ Resour 32:241-269. https://doi.org/10.1146/annurev. energy.32.041006.101434

Zeroual A, Assani AA, Meddi M, Alkama R (2019) Assessment of climate change in Algeria from 1951 to 2098 using the KöppenGeiger climate classification scheme. Clim Dyn 52:227-243. https://doi.org/10.1007/s00382-018-4128-0

Zittis G (2018) Observed rainfall trends and precipitation uncertainty in the vicinity of the Mediterranean, Middle East and North Africa. Theor Appl Climatol 134:1207-1230. https://doi.org/10.1007/ s00704-017-2333-0 
Zkhiri W, Tramblay Y, Hanich L, Jarlan L, Ruelland D (2019) Spatiotemporal characterization of current and future droughts in the High Atlas basins (Morocco). Theor Appl Climatol 135:593605. https://doi.org/10.1007/s00704-018-2388-6

Zouabi O, Peridy N (2015) Direct and indirect effects of climate on agriculture: an application of a spatial panel data analysis to
Tunisia. Clim Chang 133:301-320. https://doi.org/10.1007/ s10584-015-1458-3

Publisher's note Springer Nature remains neutral with regard to jurisdictional claims in published maps and institutional affiliations. 